\title{
TOWARDS A HIERARCHY OF RESULTATIVE CONSTRUCTIONS: THEORETICAL AND EMPIRICAL ISSUES ${ }^{1}$
}

\author{
Silvia Sánchez Calderón \\ University of Valladolid (Spain)
}

\begin{abstract}
This paper investigates how linguistic theory can account for the acquisition of the so-called English resultative constructions. It examines the syntactic dichotomies that X-Bar theory poses in their argument structure and puts forward several proposals that give answer to Chomsky's hypothesis (1981). In particular, it focuses on the ternary branching analysis and the small clause approach. Taking into account the syntactic properties of the resultative phrase (RP), a taxonomy of resultative constructions is displayed (based on Goldberg and Jackendoff, 2004) in order to test how the syntactic status of the RP is acquired by monolingual English children. As confirmed by the empirical data, the degree of syntactic complexity of the RP correlates with the age of acquisition of resultative constructions.
\end{abstract}

Keywords: resultative phrase, monolingual acquisition, X-Bar Theory, secondary predicate, CHILDES, small clause.

\section{Resumen}

Este artículo investiga cómo la teoría lingüística explica la adquisición de las denominadas construcciones resultativas en inglés. Examina las dicotomías sintácticas que plantea la teoría de la X-barra en su estructura argumental y propone diversas propuestas que dan respuesta a la hipótesis de Chomsky (1981). En concreto, se centra en el análisis ternario y el enfoque de la cláusula mínima. Teniendo en cuenta las propiedades sintácticas del sintagma resultativo (SR), se ofrece una taxonomía de construcciones resultativas (basada en Goldberg y Jackendoff, 2004) con el fin de testar cómo se adquiere el estatus sintáctico del SR en niños monolingües de lengua inglesa. Tal y como refleja en el análisis de datos empíricos, el grado de complejidad sintáctica del SR se vincula con la edad de adquisición de las construcciones resultativas.

Palabras clave: sintagma resultativo, adquisición monolingüe, Teoría de la XBarra, predicado secundario, CHILDES, cláusula mínima. 


\section{Introduction}

During the last decades, an elevated number of researchers (Goldberg and Jackendoff, 2004; Hoekstra, 2002; Levin and Rappaport-Hovav, 2001; Levin, 1994; Carrier and Randall, 1992; Nedjalkov, 1988; Chomsky, 1981; among others) have focused on the study of English resultative constructions like that in (1).

(1) It crushes it all up in pieces

(Thomas, 3;08.20, Lieven, Salomo and Tomasello's corpus, CHILDES)

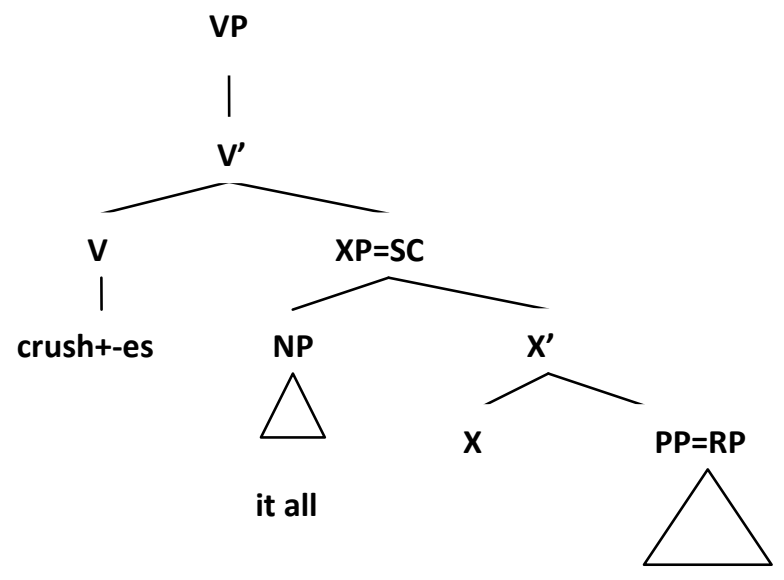

up in pieces

All of them propose that resultatives are structures where the resultative phrase (RP) describes a state or change of state. They are considered to be secondary predicates since the verbal head (V) does not subcategorize for such a predicate. Nevertheless, little attention has been paid to the acquisition of these types of complex predicates. Hence, taking into consideration the syntactic status of the RP, this study aims at analyzing how the syntactic complexity of the RP, framed in a taxonomy of resultative structures (based on Goldberg and Jackendoff, 2004) can account for their acquisition by monolingual English speakers.

This paper is organized as follows: section 2 presents a theoretical approach to resultative constructions based on the theories that deal with the syntactic status of the resultative phrase. In turn, it overviews Goldberg and Jackendoff's (2004) taxonomy of resultative structures. Section 3 proposes a re-design of Goldberg and Jackendoff's classification, which establishes the bases of this study. At the end of this section, and bearing in mind the previous theoretical 
approaches, a series of research questions are put forward with regards to how linguistic theory can account for acquisition data. Finally, section 4 concludes by establishing a connection between the degree of complexity of the RP and the age of acquisition.

\section{Theoretical background}

This section offers an overview of resultative constructions. Besides, it presents two of the theories that discuss the syntactic status of the RP. In particular, the RP is syntactically explained from the point of view of X-Bar theory and Ternary Branching analyses. It also displays Goldberg and Jackendoff's (2004) taxonomy of resultative constructions, which will be used as the basis to re-design and suggest an alternative classification.

\subsection{A general approach to resultative constructions}

Resultative clauses are, unlike in Spanish, relatively common structures in English. From a syntactic approach, they involve the elements of an independent clause along with an RP, which can be realized by an adjective phrase (AP), an adverb phrase (AdvP) or a prepositional phrase (PP). The RP, which gives the name to this construction, expresses a result which is revealed by the syntactic structure of their arguments. As can be seen in (1) above, the RP it all in pieces adds a resultative state to the verbal action.

They are considered to be secondary predicates because the $\mathrm{V}$ does not subcategorize for such predicates in relation to the semantics of the clause. Despite that, as exemplified in (2), the V called is able to select the RP horrid, which functions as predicate of the direct object $(\mathrm{Od})$ argument me. In turn, the $\mathrm{RP}$ adds more information to the clausal structure. 
(2) Everybody called me horrid

(Thomas, 3;05, Lieven, Salomo and Tomasello's corpus, CHILDES)

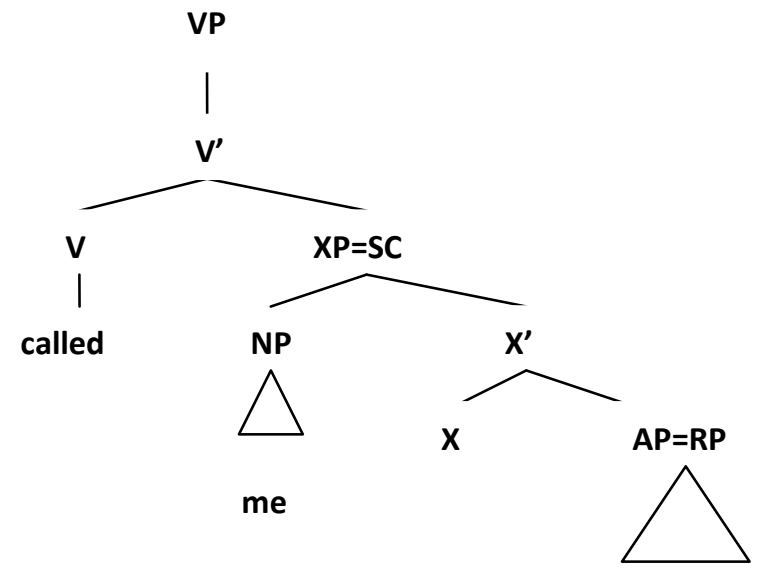

horrid

\subsection{Theories that deal with the syntactic status of the resultative phrase}

This section reviews the dichotomies that the resultative phrase (RP) has posed in the literature of resultative constructions. On the one hand, it displays how the status of the RP is given regarding the X-Bar theory (Chomsky, 1981). On the other hand, an alternative approach is discussed, following Carrier and Randall's 1992 Ternary Analysis.

\subsubsection{Chomsky's (1981) X-Bar theory}

As illustrated in (3), X-Bar Theory (Chomsky, 1981) resorts to three basic principles which explain the innate acquisition of a language in an early age.

a) The complement rule: this principle establishes that a head $\mathrm{X}$ must combine with a complement (YP), projecting an intermediate projection ( $\left.\mathrm{X}^{\prime}\right)$.

b) The adjunct rule: it establishes that an adjunct combines with an intermediate projection (X') and, in turn, it projects another intermediate projection ( $\mathrm{X}$ "). The adjunct rule is optional and recursive, that is to say, it is applied if and only if there is an adjunct and it can be applied as many times as adjuncts there are in a clause. 
c) The Maximal Projection rule: it claims that an intermediate projection (X', X', $\mathrm{X}^{\prime \prime}$, , etc.) projects a maximal projection (XP), combining in the socalled specifier position (ZP) optionally.

(3) X-Bar Theory

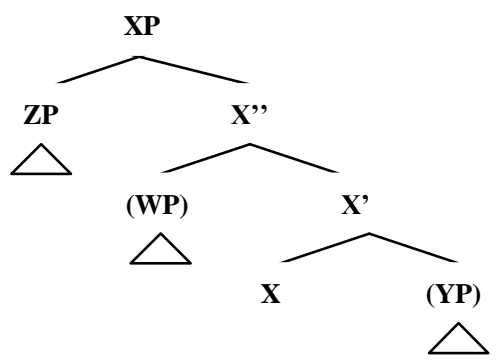

A resultative clause poses some issues regarding X-Bar Theory as far as the status of the RP is concerned: it can be considered as a verbal complement or an adjunct. Following the X-Theory principles, the RP should be understood as an adjunct, assuming that it is a constituent which functions semantically as a verbal modifier. In this manner, we can see that the syntactic structure supported for these phrases (adjuncts) is not related to their semantic interpretation (secondary predicates of the verbal complement). In other words, resultative constructions do not observe X-Bar Theory since they generate binary branches and, consequently, the RP cannot be subcategorized by V.

\subsubsection{Carrier and Randall's (1992) Ternary Branching}

Carrier and Randall (1992) resort to the Ternary Analysis in order to explain Chomsky's (1981) binary branching dichotomy. The result of such an analysis, as shown in (4), is the interpretation of the internal verbal argument and the RP within a ternary branching in the maximal projection of the verb phrase (VP). 
(4) It crushes it all up in pieces

(Thomas, 3;08.20, Lieven, Salomo and Tomasello's corpus, CHILDES)

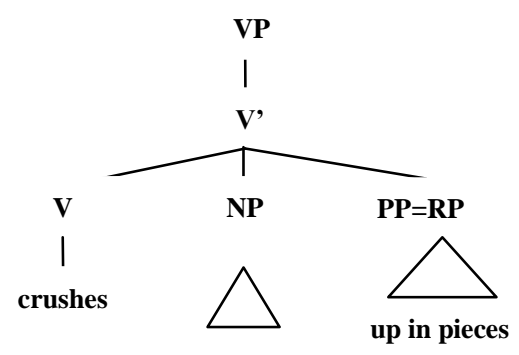

it all

The Ternary Analysis explains the syntactic structure of resultative constructions, since V subcategorizes for three arguments: an external argument (not represented in (4)) that is realized in order to meet the Extended Projection Principle (Chomsky, 1981), and two internal arguments, which, taking into account their semantics, receive the theme and result theta roles, ${ }^{1}$ respectively. Thus, the internal nominal argument (NP) and RP are, within the D(eep)Structure, verbal sisters. In other words, the RP adopts a thematic role thanks to the power of subcategorization and thematization of the verb. Due to the fact that V subcategorizes for two arguments, Carrier and Randall (1992) point out a subject-predicate relation between the internal NP and the RP. However, taking into account the semantic approach, although both phrases express the same event, they do not make up a single syntactic constituent. Therefore, it all up in pieces in (4) implies that the verbal complement breaks down and a state of splitting up in several pieces takes place.

\subsection{A taxonomy of resultative constructions}

Section 2.3 displays Goldberg and Jackendoff's (2004) taxonomy of resultative constructions from a syntactic point of view. Taking their premises into account, a re-classification of Goldberg and Jackendoff's classification is proposed, according to the syntactic status of the RP. In particular, resultative

\footnotetext{
${ }^{1}$ Cf. The Uniformity of Theta Assignment Hypothesis (UTAH, Baker, 1988:46).
} 
structures are classified depending on whether the RP is encoded in the lexicon, in the syntax or in both.

\subsubsection{Goldberg and Jackendoff's (2004) classification of resultative constructions}

Goldberg and Jackendoff (2004) have established a classification mainly based on the syntactic interpretation of the RP. Nevertheless, as will be shown in the empirical study (see section 3), children need to take into account both the syntax and semantics.

\section{- Intransitive resultatives (IntrR)}

The verbal constituent in IntrRs subcategorizes for an internal argument (RP) which is theta-marked by $\mathrm{V}$ (see example (5)).

(5) The pond froze solid (RP=AP) (Goldberg and Jackendoff: 536)

\section{- Selected Transitive resultatives (SelecTrR)}

A SelecTrR subcategorizes for a Od, considering the RP as part of the subcategorization framework. As displayed in (6), the $\mathrm{V}$ water subcategorizes for two internal arguments, a Od the flowers and An AP flat.

(6) The gardener watered the flowers flat (RP=AP) (Goldberg and Jackendoff: 536)

\section{- Unselected transitive resultatives (UnselecTrR)}

The verbal head in UnselecTrRs subcategorizes for a Od which is not independently selected by V (see example (7)).

(7) They drank the pub $\underline{\text { dry }}(\mathrm{RP}=\mathrm{AP}) \quad$ (Goldberg and Jackendoff: 536)

*They drank the pub

\section{- Fake Reflexive resultatives (FreflR)}

FreflRs are a special case of UnselecTrRs where, as shown in the example (8), a reflexive object cannot be replaced by a NP.

(8) We yelled ourselves hoarse (Goldberg and Jackendoff: 536)

*We yelled Harry hoarse

\section{- Property resultatives (PropR)}

PropRs make reference to a change of property (see example (9) below).

(9) Harry coughed himself into insensibility (Goldberg and Jackendoff: 537) 


\section{- Spatial Path resultatives (SpaR)}

SpaRs, as illustrated in (10), are constructions where the RP has a spatial path configuration. From a syntactic viewpoint, such phrases are preceded by PPs or APs such as apart, clear of $N$, free of NP, open and shut.

(10) He jumped clear of the traffic (Goldberg and Jackendoff: 558)

\section{- Causative resultatives (CausR)}

In CausRs, the Od functions as the subject (or host) of the resultative construction and it is caused by the subject to undergo a change of state or position. As exemplified in (11) above, the clausal subject Bill causes the ball to undergo a movement down the hill.

(11) Bill rolled the ball down the hill (Goldberg and Jackendoff: 540)

\subsubsection{Redesigning Goldberg and Jackendoff's (2004) classification of resultative constructions}

This study proposes an alternative classification of resultative constructions, based on Goldberg and Jackendoff (2004), displayed in section 2.3.1. In other words, this taxonomy takes into consideration the locus where the result state is encoded (i.e., in the lexicon, in the syntax, or in both): (a) Phrasal Verb resultatives (PVR), based on Goldberg and Jackendoff's spatial resultatives, when the result state is encoded in the lexicon, (b) Basic resultatives (BRs), founded on Golbderg and Jackendoff's property resultatives, when the result state is encoded in the syntax, and (c) Real resultatives (RRs), merging Goldberg and Jackendoff's (Un)-SelecTrRs, IntrRs, FreflRs and CausRs when the result state is encoded both in the lexicon and in the syntax. That is to say, in RRs, V selects a small clause (SC) which is not subcategorized for, and the fact that V is able to select it as a complement comes from semantic reasons.

\subsubsection{Phrasal Verb resultatives (PVR)}

PVRs are lexicalized, that is to say, they are constructions which already include the resultative state in the semantics of $\mathrm{V}$ and subcategorize for their internal arguments. 
(12) Sit down

(Ella, 1;07, Forrester's corpus, CHILDES)

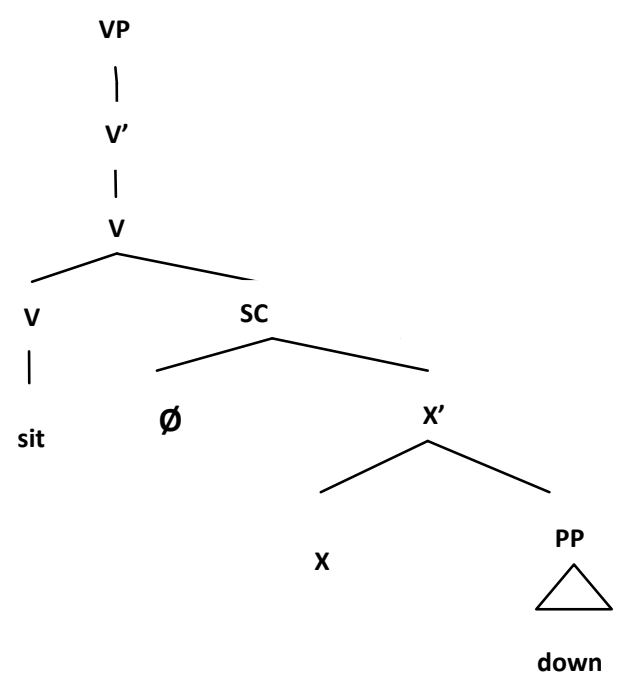

This study argues that PVRs like (12) denote a result that is already codified in the lexical entry of $\mathrm{V}$. Therefore, the acquisition of this type of resultatives takes place early. If this kind of structures were analyzed by pursuing Hoekstra's (2002) analysis, PVRs would be subcategorized for as SCs. As will be shown by the data in section 3, Hoekstra's analysis cannot be on the right track when applied to PVR acquisition because these Vs are acquired earlier than SCs.

\subsubsection{Basic resultatives $(\mathrm{BR})$}

BRs are those structures consisting of the verbs get, make and take. They are more complex structures than PVRs because they take SCs as complements. BRs are classified because the $\mathrm{SC}$ is subcategorized by $\mathrm{V}$.

As illustrated in in (13), the V (get) subcategorizes for a SC (sick) which is a secondary predicate, expressing the predication you are sick. This secondary predication is added to the primary predication you get. The subject of the SC moves from the specifier of the SC to the subject position of the main clause. 
(13) You will get sick ${ }^{2}$

(Ella, 2;09, Forrester's corpus, CHILDES)

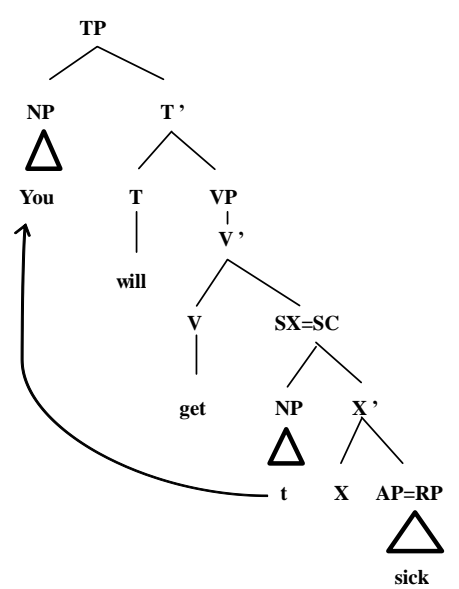

The transitive version of (13) would be example (14), taken from the dictionary of Linguee corpus (Frahling, 2014), where there is no movement of the subject in the SC.

(14) Marcellin's mother, though, worked [to get him back into the seminary $]^{3}$

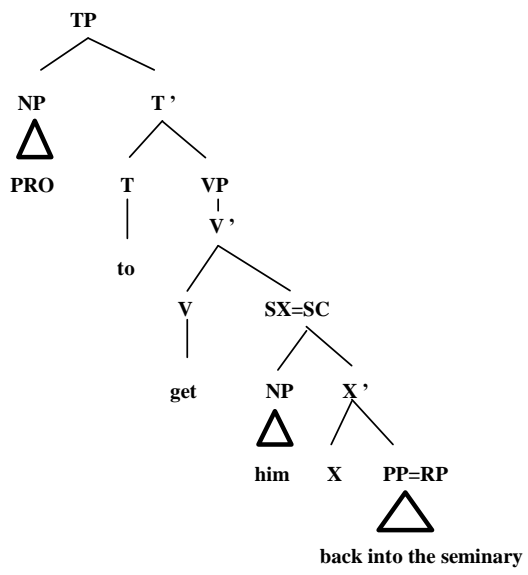

${ }^{2}$ Recall that TP stands for Tense Phrase, T stands for Tense (cf. Chomsky, 1981).

${ }^{3}$ For more information about the empty category PRO, see Chomsky (1981). 


\subsubsection{Real resultatives $(\mathrm{RR})$}

RRs, as represented in (15), are those constructions whose Vs do not have the capacity to subcategorize for an SC, despite the fact that they can select an SC. From a syntactic point of view, they present a secondary predication.

(15) Crushes it all up in pieces (Thomas, 3;08.20, Lieven, Salomo and Tomasello's corpus, CHILDES) ${ }^{4}$

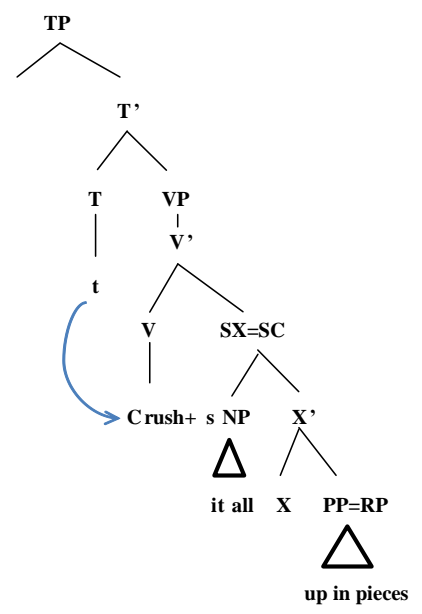

In (15), the $\mathrm{V}$ crush presents an internal argument within its subcategorization framework (it all) and the PP up in pieces is not a constituent subcategorized by V. However, the V crush selects an SC and relates the NP it all to the $\mathrm{PP}$ up in pieces by means of a predicative relation. Note again that this $\mathrm{SC}$ is not subcategorized by $\mathrm{V}$. Thus, the fact that the $\mathrm{V}$ can subcategorize is due to semantic reasons, whose nature is left aside due to space constraints.

\section{The study}

Through a series of hypothesis and Research Questions, a re-classification of Goldberg and Jackendoff's (2004) taxonomy will be checked against empirical data. Therefore, this empirical study will describe and analyze how the syntactic and lexical complexity of the RP is acquired by monolingual English children.

\footnotetext{
${ }^{4}$ It should be remarked that Thomas' production of this resultative utterance has been construed with clausal subject omission.
} 


\subsection{Hypothesis and Research Questions}

Taking into account the re-classification of resultative constructions (put forward in section 2.3.2), the main hypothesis (Ho) which revolves around this study and that, in turn checks this taxonomy of resultatives against empirical data is the following:

Ho: Constructions sensitive to semantic factors are acquired later than constructions that are set due to syntactic factors, and, in turn, they will be acquired later than constructions that are sensitive to other lexical factors. Therefore:

a. PVRs will be acquired earlier than BRs and RRs.

b. BRs will be produced earlier than RRs.

c. RRs will be acquired later than PVRs and BRs due to syntactic and semantic restrictions.

A series of research questions are put forward to show how the linguistic theory can account for the acquisition data:

1. Are resultative structures (PVRs, BRs, and RRs) acquired at the same stage?

2. Does the degree of syntactic and lexical complexity determine the way resultatives are acquired?

\subsection{Data selection}

Data selection has been carried out by resorting to the CHILDES project (MacWhinney, 2000). The corpora that have been selected include data from monolingual L1 English children and they are the following: the Forrester corpus (Forrester, 2002) which compiles data from the child Ella; the Lieven, Salomo and Tomasello's corpus (2009), which includes data from the child Thomas; and the Rowland and Fletcher's corpus (2006), which contains data from the child Lara.

All the participants in the study are British, white, and middle class. More specifically, Michael Forrester (Forrester 2002) carried out a longitudinal study of the development of his daughter (Ella)'s conversational skills. Ella was born in January 1997 and the study was conducted between the ages of 1;00 (one year) and 3;6 (three years and six months). In turn, Lieven, Salomo, and Tomasello' corpus (2009) comprises a longitudinal naturalistic study of the child Thomas over a period of three years (age range: $2 ; 0-4 ; 11$, i.e., between two years and four years and eleven months). The data are based on interactions between his primary care-giver (his mother) and him. Lara's corpus (Rowland and Fletcher, 2006) consists of conversations of this child interacting with her caregivers between 1;09 (one year and nine months) and 3;03 (three years and three months). She was the first-born monolingual English daughter of two white 
university graduates, born and bred in Nottinghamshire; however, there are no many regional dialectical terms in her speech.

\subsection{Data classification and analysis}

The data have been codified according to a re-classification of Goldberg and Jakckendoff's (2004) hierarchy of resultative constructions (see section 2.3.2). As displayed in table 1 below, 26 utterances have been found in Ella's output, out of 17 utterances corresponded to PVRs and 9 to BRs (see appendix 1). No instances of RRs have been found. Concerning Thomas' study, among the 226 utterances that have been analyzed, 194 include PVRs, 31 BRs and one instance of RR (see appendix 2). In Lara's speech, we have obtained 211 utterances, among which, 166 are PVRs and 45 utterances encompass BRs. As in Ella's speech, no piece of evidence for RRs has been found (see appendix 3).

Table 1. Total number of utterances gathered for each type of resultative construction

\begin{tabular}{llll}
\hline & PVR & BR & RR \\
\hline Ella & 17 & 9 & 0 \\
Thomas & 194 & 31 & 1 \\
Lara & 166 & 45 & 0 \\
\hline
\end{tabular}

Examples in (16), (17) and (18) illustrate some of the resultative constructions produced by the participants.

(16) If you eat all up CHILDES)

(17) To make her better Tomasello's corpus, CHILDES)

(18) Crushes it all up in pieces Tomasello's corpus, CHILDES)
(PVR, Ella, 2;09, Forrester's corpus,

(BR, Thomas, 2;04, Lieven, Salomo and

(RR, Thomas, 3;08, Lieven, Salomo and

Considering the total number of resultative structures that the children uttered in their corresponding corpus (see appendix for more information), it is not until the age of 1;07, 2;01 and 1;09 that Ella, Thomas and Lara start producing of PVRs, respectively. Those early productions are syntactically simple since the resultative state is encoded in the lexicon. In other words, and as shown in table 2, the evidence that we find between the ages of 1;07 and 2;01 is based on Vs which have a lexicalized RP. This syntactic simplicity explains the high frequency in their productions, as illustrated in table 1 above. 
Table 2. Age of first occurrence of resultative constructions

\begin{tabular}{llll}
\hline & PVR & BR & RR \\
\hline Ella & $1 ; 07$ & $2 ; 05$ & $\varnothing$ \\
Thomas & $2 ; 01$ & $2 ; 04$ & $3 ; 08$ \\
Lara & $1 ; 09$ & $2 ; 04$ & $\varnothing$ \\
\hline
\end{tabular}

The subsequent type of resultatives to be acquired by the children is BRs consisting of the Vs get/make/take along with the $\mathrm{V}$ call. The data from Ella, Thomas and Lara show that the first BR productions are present at 2;05 (Ella) and 2;04 (Thomas and Lara). Similarly, RRs are present in Thomas' speech at the age of 3;08. However, only example (19) has been found of these latter constructions in Thomas' speech.
(19) Crushes it all up in pieces
(Thomas, 3;08.20, Lieven, Salomo and Tomasello's corpus, CHILDES)

It should be noted that no RRs have been attested in Lara or Ella, which supports a later acquisition of this kind of resultatives. In other words, the lack of RRs in Lara and Ella leads us to conclude that the acquisition of this type of resultatives takes place after the age of 3;09.

Furthermore, and as stated in section 2, the absence of structural differences between PVRs and BRs is manifested in the correlated age of early acquisition at around the age of 2. For example, as represented in (20a-b), Thomas begins to produce PVRs and BRs at 2;01 and 2;04, respectively, which, from a syntactic point of view, this correlation in age could be explained by the analogous status given to the RP in both constructions. In other words, the RP down in the PVR in (20a) and the RP better in the BR in (20b)) are encoded in the argument structure of an SC. 
(20) a. Get down

Salomo and Tomasello's corpus, CHILDES)

(PVR, Thomas, 2;01, Lieven,

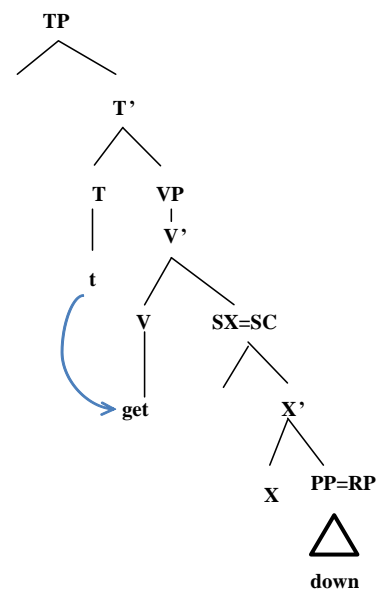

b. Make her better

(BR, Thomas, 2;04, Lieven, Salomo and Tomasello's corpus, CHILDES)

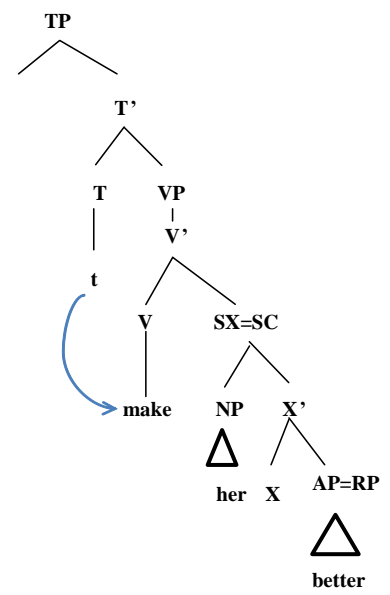

If PVRs were structurally similar to BRs, then it would be expected that they are acquired concurrently. However, the evidence found in the data analyzed contradicts this prediction: PVRs are produced earlier than BRs in the three participants (see table 2). This means that the syntactic structure of these Vs must be simpler than the syntactic structure of BRs, supporting, in this way, the fact that PVRs have a verbal head which codifies the result state in the lexicon rather than in the syntax. Therefore, a division is seen between the lexicon and syntax. The different types of resultatives and the data presented 
here support this division: the RP which is codified in the lexicon (PVRs) is acquired earlier than the RP which codified in the syntax (BRs). PVRs have the result state already codified in their structure, which allows the child to acquire it at an early stage. Nevertheless, BRs and RRs are associated with more complex syntactic structures. Furthermore, the latter type of resultatives (RRs) does not subcategorize for a SC (i.e. a RP) but other semantic factors are responsible for its license. Therefore, we argue that RRs are acquired later than BRs, and, in turn, BRs are acquired later than PVRs. This is confirmed by the empirical data analyzed, illustrated in our results in table 2.

\section{Conclusion}

Due to the syntactic dichotomies in the literature concerning the argument structure of resultative constructions (Carrier and Randall, 1992; Chomsky, 1981), those issues can be solved without the need to resort to Carrier and Randall's (1992) Ternary Analysis, discussed in section 2.2.2. Instead, Stowell's (1981) hypothesis is followed since it establishes the foundation for the formation of resultative constructions, and he considers the RP as a constituent subcategorized by the $\mathrm{V}$ within a small clause (SC) domain. Yet, unlike monotransitive clauses, it cannot be inferred that the RP in the re-classification of resultative constructions, displayed in section 2.3.2, is lexically selected by V. Thus, the RP in PVRs, BRs and RRs is not an adjunct, but part of a SC, satisfying the principles of X-Bar Theory.

The status given to the RP as an argument which is encoded in a SC goes hand in hand with the age of acquisition of PVRs and BRs since both utterances begin to be produced by the children at around the age of 2 . Nevertheless, Thomas' later production of RRs at 3;08 (three years and eight months) suggests that the RP in RRs could have a different syntactic status from the RP in PVRs and BRs. Moreover, the lack of data found of RRs in Ella's and Lara's corpus cannot offer concluding results as to whether the status granted to the RP in RRs is analogous to the status given to the RP in PVRs and BRs. Thus, further research is required with a broader selection of corpora in order to draw more standing conclusions.

\section{Notes}

${ }^{1}$ A version of this paper has been presented at the Asociación de Jóvenes Lingüistas (AJL -Young Linguists Association) conference held at the University of Murcia (Spain), 3-5 September, 2014. Financial support to participate has been provided by the University of Valladolid. I would like to thank Raquel Fernández Fuertes and Ismael Iván Teomiro García for their comments and support. All remaining errors are my own. 


\section{WORKS CITED}

Baker, M. C. Incorporation: A Theory of Grammatical Function Changing. The University of Chicago Press: London, 1988.

Carrier, J. and J. H Randall. "The argument structure and syntactic structure of Resultatives." Linguistic Inquiry 23 (1992):173-234.

Chomsky, N. Lectures on Government and Binding. Foris: Dordrecht, 1981.

Forrester, M. "Appropriating cultural conceptions of childhood: Participation in conversation." Childhood 9 (2002): 255-278.

Frahling, G. Linguee. Consulted on $10^{\text {th }}$ February in 2014 in <www.linguee.com>. [corpus dictionary], 2014.

Goldberg, A. and R. Jackendoff. "The English Resultative as a family of constructions." Language 80 (2004): 532-568.

Hoekstra, T. "Small clause results." Lingua 74 (2002):101-139.

Levin, B. English Verb Classes and Alternations: A Preliminary Investigation. New York: University of Chicago Press, 1994.

Levin, B. and M. Rappaport Hovav. "An event structure account of English Resultatives." Language 77 (2001):766-797.

Lieven, E., D. Salomo and Tomasello, M. "Two year old children's production of multiword utterances: A usage-based analysis." Cognitive Linguistics 20 (2009): 481-508.

MacWhinney, B. The CHILDES project: Tools for analyzing talk. Third Edition. Mahwah, NJ: Lawrence Erlbaum, 2000.

Nedjalkov, V. P. Typology of Resultative Constructions. Russia: John Benjamins Publishing Company, 1988.

Rowland, C.F. and S.L. Fletcher. "The effect of sampling on estimates of lexical specificity and error rates." Journal of Child Language 33 (2006):859877.

Stowell, T. Origins of Phrase Structure. PhD Dissertation, MIT, 1981. 
Appendix 1: resultative constructions collected in Ella (Forrester's corpus,

CHILDES, MacWhinney, 2000)

\begin{tabular}{|c|c|c|c|}
\hline YEAR & MONTH & $\begin{array}{c}\text { TYPE OF } \\
\text { RESULTATIVE }\end{array}$ & UTTERANCE \\
\hline 1 & 00 & $\varnothing$ & $* \mathrm{CHI}: \varnothing$ \\
\hline 1 & 00 & $\varnothing$ & $* \mathrm{CHI}: \varnothing$ \\
\hline 1 & 01 & $\varnothing$ & $* \mathrm{CHI}: \varnothing$ \\
\hline 1 & 01 & $\varnothing$ & $* \mathrm{CHI}: \varnothing$ \\
\hline 1 & 02 & $\varnothing$ & ${ }^{*} \mathrm{CHI}: \varnothing$ \\
\hline 1 & 02 & $\varnothing$ & $* \mathrm{CHI}: \varnothing$ \\
\hline 1 & 03 & $\varnothing$ & $* \mathrm{CHI}: \varnothing$ \\
\hline 1 & 04 & $\varnothing$ & $* \mathrm{CHI}: \varnothing$ \\
\hline 1 & 05 & $\varnothing$ & $* \mathrm{CHI}: \varnothing$ \\
\hline 1 & 05 & $\varnothing$ & $* \mathrm{CHI}: \varnothing$ \\
\hline 1 & 07 & PVR & $\begin{array}{l}* \text { *HI: sit down } \\
* \text { CHI: did a bit fall down }\end{array}$ \\
\hline 1 & 08 & $\varnothing$ & $* \mathrm{CHI}: \varnothing$ \\
\hline 1 & 09 & $\varnothing$ & $* \mathrm{CHI}: \varnothing$ \\
\hline 1 & 10 & $\varnothing$ & $* \mathrm{CHI}: \varnothing$ \\
\hline 2 & 00 & PVR & $*$ CHI: sit down properly \\
\hline 2 & 02 & PVR & $\begin{array}{l}\text { *CHI: rain comes down frop } \\
\text { comes up }\end{array}$ \\
\hline 2 & 03 & $\varnothing$ & $* \mathrm{CHI}: \varnothing$ \\
\hline 2 & 03 & $\varnothing$ & $* \mathrm{CHI}: \varnothing$ \\
\hline 2 & 03 & $\varnothing$ & $* \mathrm{CHI}: \varnothing$ \\
\hline 2 & 04 & $\varnothing$ & $* \mathrm{CHI}: \varnothing$ \\
\hline 2 & 05 & $\begin{array}{l}\text { PVR } \\
\text { BR }\end{array}$ & $\begin{array}{l}\text { *CHI: [don't take] my spoon } \\
\uparrow a w a:: y \\
\text { *CHI:I got full up }\end{array}$ \\
\hline 2 & 06 & PVR & *CHI: fallin down \\
\hline 2 & 07 & $\begin{array}{l}\text { BR } \\
\text { PVR }\end{array}$ & $\begin{array}{l}{ }^{*} \text { CHI: gonna get clean all of it out } \\
{ }^{*} \text { CHI: not climbing up }\end{array}$ \\
\hline 2 & 08 & BR & *CHI: it's gonna get broken \\
\hline 2 & 09 & PVR & ${ }^{*}$ CHI: $\quad$ if you eat it all up $\rightarrow$ \\
\hline
\end{tabular}




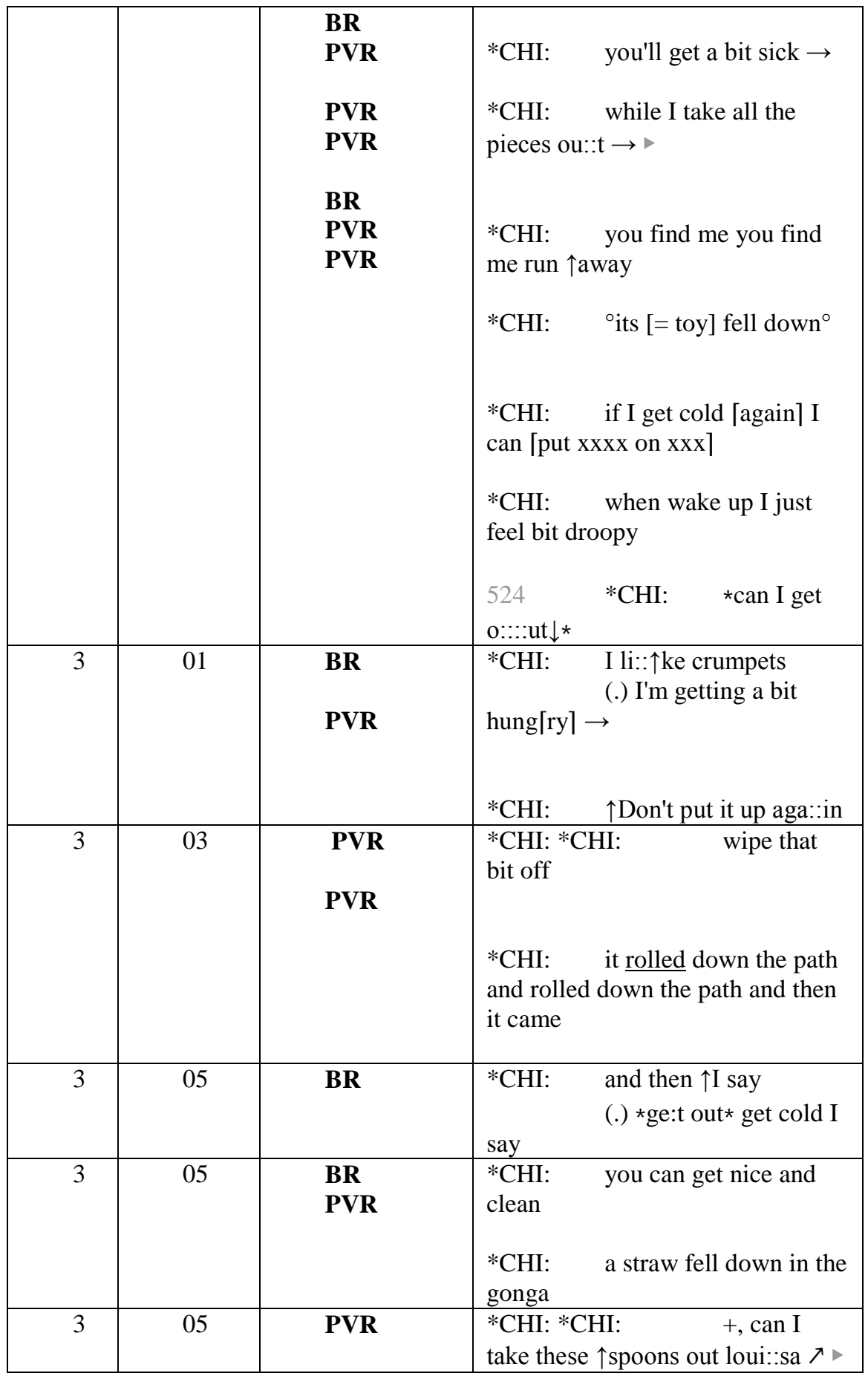




\begin{tabular}{|l|l|l|l|}
\hline 3 & 09 & BR & $\begin{array}{l}* \text { CHI: small red one and have } \\
\text { one of those at the end in case you } \\
\text { get all red } \rightarrow\end{array}$ \\
\hline
\end{tabular}


Appendix 2: resultative constructions collected in Thomas (Lieven, Salomo and Tomasello's corpus, CHILDES, Macwhinney, 2000)

\begin{tabular}{|c|c|c|c|}
\hline YEAR & MONTH & $\begin{array}{c}\text { TYPE OF } \\
\text { RESULTATIVE }\end{array}$ & UTTERANCE \\
\hline 2 & 00 & $\varnothing$ & $\varnothing$ \\
\hline 2 & 01 & PVR & $\begin{array}{l}* \text { CHI: seat down there } \\
{ }^{*} \text { CHI: get [?] down }\end{array}$ \\
\hline 2 & 02 & $\varnothing$ & $\varnothing$ \\
\hline 2 & 03 & PVR & $\begin{array}{l}* \text { CHI: sit down } \\
\text { *CHI: get down }\end{array}$ \\
\hline 2 & 04 & $\begin{array}{l}\text { BR } \\
\text { PVR } \\
\text { PVR }\end{array}$ & $\begin{array}{l}\text { *CHI: where the doctors are } \\
\text { going to make her better } \\
\text { *CHI: turn it off } \\
\text { *CHI: Mummy sit down } \\
\text { Thomas } \\
* \text { CHI: sit }[<] \text { down }\end{array}$ \\
\hline 2 & 05 & $\begin{array}{l}\text { PVR } \\
\text { PVR } \\
\text { BR }\end{array}$ & $\begin{array}{l}\text { *CHI: no sit up } \\
\text { *CHI: Mummy sit down } \\
\text { *CHI: fall down a@p kitchen } \\
\text { *CHI: fall over } \\
\text { *CHI: Dimitra sit down } \\
\text { *CHI: run away } \\
\text { *CHI: <put it> [?] away } \\
\text { *CHI: a@p run away } \\
\text { *CHI: get changed }\end{array}$ \\
\hline 2 & 06 & PVR & $\begin{array}{l}\text { *CHI: fallen off } \\
* \text { CHI: bus 0has [*] fallen over }\end{array}$ \\
\hline
\end{tabular}




\begin{tabular}{|c|c|c|c|}
\hline & & PVR & $\begin{array}{l}\text { and the train Ohas [*] fallen over } \\
\text { *CHI: Mummy sit down } \\
\text { *CHI: rolling down } \\
\text { *CHI: xxx a@p throw them [?] } \\
\text { out } \\
\text { *CHI: a tractor come [*] pull it } \\
\text { *CHI: leaves fall off a @ p tree } \\
\text { out } \\
\text { *CHI: not fall out } \\
\text { *CHI: get out } \\
\text { *CHI: setting off . } \\
\text { *CHI: big fire <gone out> } \\
\text { *CHI: big fireman setting off } \\
\text { *CHI: oh fall over <the leaf> } \\
\text { *CHI: sit down, Dimitra } \\
\text { *CHI: no put them down } \\
\text { *CHI: a @ petting out a@p } \\
\text { ladder come } \\
\text { *CHI: lift out } \\
\text { *CHI: get out } \\
\text { *CHI: pick it up } \\
\text { *CHI: the eyes come off } \\
\text { *CHI: lift it up }\end{array}$ \\
\hline 2 & 07 & PVR & $\begin{array}{l}\text { *CHI: run away } \\
\text { *CHI: a@p gone away now } \\
\text { *CHI: put it away } \\
\text { *CHI: run away } \\
\text { *CHI: lie down } \\
\text { *CHI: a } @ \text { p fall over }\end{array}$ \\
\hline
\end{tabular}




\begin{tabular}{|c|c|c|c|}
\hline & & & $\begin{array}{l}\text { *CHI: a piece fall [*] over } \\
\text { *CHI: ladders fall [*] down } \\
\text { *CHI: xxx leaf come off } \\
\text { *CHI: xxx <stand up> } \\
\text { *CHI: all fall down now } \\
\text { *CHI: oh sit down . } \\
\text { *CHI: lie down . } \\
\text { *CHI: come and sit down } \\
\text { *CHI: come out } \\
\text { *CHI: dig it out } \\
\text { *CHI: fall out window } \\
\text { *CHI: push them all out } \\
\text { *CHI: throw it out } \\
\text { *CHI:yeah lorry <go through> } \\
\text { *CHI: a @ p bridge fall down } \\
\text { *CHI: stand up } \\
\text { *CHI: fall over } \\
\text { *CHI: take it off } \\
\text { *CHI: that picture sunshine } \\
\text { comes out aHI: me man [=! babble] } \\
\text { *CHe the } \\
\text { drive off } \\
\text { *CHI: let's [?] break it up } \\
\text { *CHI: let's [?] break it up } \\
\text { *CHI: leaves blowing off }\end{array}$ \\
\hline 2 & 08 & PVR & $\begin{array}{l}\text { *CHI: erm let's sit down } \\
\text { *CHI: erm stretch it out } \\
\text { *CHI: fell [= actually says fall] } \\
\text { down my side } \\
\text { *CHI: cake fell down } \\
\text { *CHI: empty all a @p rubbish } \\
\text { out } \\
\text { *CHI: Mummy sit down } \\
\text { *CHI: lie down } \\
\text { *CHI: running off } \\
\text { *CHI: sit down my side } \\
\text { *CHI: going up } \\
\text { *CHI: get down } \\
\text { *CHI: sit down my side } \\
\text { *CHI: going up } \\
\text { *CHI: get down } \\
\text { *CHI: turn that light off } \\
\text { *CHI: a @ p my get down <off } \\
\text { them> }\end{array}$ \\
\hline
\end{tabular}




\begin{tabular}{|c|c|c|c|}
\hline & & & $\begin{array}{l}\text { *CHI: make balloon orange } \\
\text { sausage } \\
\text { *CHI: got wet }\end{array}$ \\
\hline & & & *CHI: run away \\
\hline \multirow[t]{3}{*}{2} & \multirow[t]{3}{*}{09} & PVR & $\begin{array}{l}\text { *CHI: xxx fall down } \\
\text { *CHI: get down now } \\
\text { *CHI: please get me down } \\
\text { *CHI: press it down } \\
\text { *CHI: Jess fall [*] down } \\
\text { *CHI: get down } \\
\text { *CHI: it-'has fallen down } \\
\text { *CHI: take your cushion off } \\
\text { *CHI: put it down there } \\
\text { *CHI: come down } \\
\text { *CHI: get out } \\
\text { *CHI: oh sit down }\end{array}$ \\
\hline & & BR & 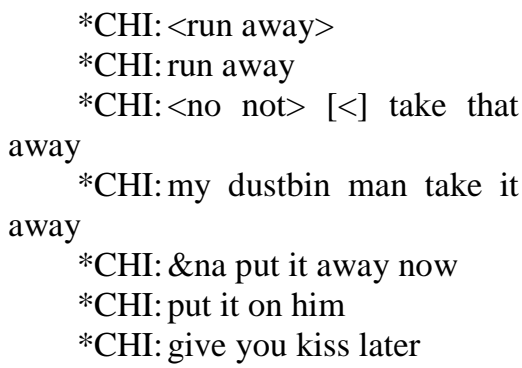 \\
\hline & & & $\begin{array}{l}\quad * \text { CHI: making all pink } \\
\quad * \text { CHI: Daddy get dry there [?] } \\
\text { please } \\
{ }^{* C H I} \text { : Gordon get } \\
\text { frightened }\end{array}$ \\
\hline 2 & 10 & PVR & $\begin{array}{l}* \text { CHI: ++ ran down } \\
\text { *CHI: all fall down } \\
\text { *CHI: xxx fall over } \\
\text { *CHI: <put it in here> }\end{array}$ \\
\hline
\end{tabular}




\begin{tabular}{|c|c|c|c|}
\hline & & BR & $\begin{array}{l}\text { *CHI: throw the money down } \\
\text { *CHI: come up } \\
\text { *CHI: eating all up } \\
\text { *CHI: turn the light off } \\
\text { *CHI: run away } \\
\text { *CHI: Lala's not waking up } \\
\text { *CHI: get it [?] down } \\
\text { *CHI: I wash up } \\
\text { *CHI: press her down } \\
\text { *CHI: a @ p wipe your kiss off } \\
\text { *CHI: <that make> [/] that } \\
\text { make my legs sore } \\
\text { *CHI:I get her better }\end{array}$ \\
\hline 2 & 11 & PVR & $\begin{array}{l}\text { *CHI: and take all letters away } \\
{ }^{*} \mathrm{CHI} \text { : put your jumper out } \\
{ }^{*} \mathrm{CHI}:<\text { they fell over> } \\
{ }^{*} \mathrm{CHI} \text { : take a } @ \text { p ring out now } \\
{ }^{*} \mathrm{CHI} \text { you go away } \\
{ }^{*} \mathrm{CHI} \text { : I get out } \\
{ }^{*} \mathrm{CHI} \text { um jump out of (th)em } \\
\text { like that }\end{array}$ \\
\hline & & BR & $\begin{array}{l}\quad * \text { CHI: make her better } 487 \\
\quad * \text { CHI: }<\text { I eat }[/] \text { I eat }>[<][/] \text { I } \\
\text { eat Purdie's food that my make my } \\
\text { sick }\end{array}$ \\
\hline 3 & 00 & PVR & $\begin{array}{l}\text { *CHI:Fireman_Sam-'has put it } \\
\text { away } \\
\text { *CHI: an(d) run (a)way again } \\
\text { *CHI: you nearly spit out } \\
\text { *CHI: he-'has put his ladders up } \\
\text { *CHI: got me out of my seat } \\
\text { *CHI: got my finger stuck } \\
\text { *CHI:I am [*] always calling } \\
\text { him man }\end{array}$ \\
\hline 3 & 01 & $\begin{array}{l}\text { BR } \\
\text { PVR }\end{array}$ & $\begin{array}{l}\text { CHI: I call him ginger ginger } \\
\text { weasel } \\
{ }^{*} \text { CHI: then sit down } \\
{ }^{*} \text { CHI: I just get out } \\
{ }^{*} \text { CHI: get down }\end{array}$ \\
\hline
\end{tabular}




\begin{tabular}{|c|c|c|c|}
\hline & & & *CHI: I get him something else \\
\hline 3 & 02 & $\begin{array}{l}\text { BR } \\
\text { PVR }\end{array}$ & $\begin{array}{l}\text { *CHI: (be)cause it get me upset } \\
{ }^{*} \text { CHI: throw that away }\end{array}$ \\
\hline 3 & 03 & PVR & $\begin{array}{l}\text { *CHI: erm the field it comes off } \\
{ }^{*} \text { CHI: Purdie, go away } \\
{ }^{*} \text { CHI: it's coming out of the } \\
\text { tunnel } \\
\text { *CHI: (be)cause (.) you get } \\
\text { your tummy all tired }\end{array}$ \\
\hline 3 & 04 & PVR & $\begin{array}{l}{ }^{*} \text { CHI: uhm I can't reach up } \\
\text { because I need to kneel down on } \\
\text { the road } \\
{ }^{*} \text { CHI: look this man's } \\
\text { collecting all the diggers and taking } \\
\text { all the men away } \\
{ }^{*} \text { CHI: I give you three }\end{array}$ \\
\hline 3 & 05 & PVR & $\begin{array}{l}\text { *CHI: two thumbs put them up } \\
{ }^{*} \text { CHI: we fall down . } \\
{ }^{*} \text { CHI: hey don't throw it away } \\
{ }^{*} \text { CHI: drink it up } \\
{ }^{*} \text { CHI: pass 0it [*] to Mummy . } \\
{ }^{*} \text { CHI: I'm going to deliver you } \\
\text { some milk } \\
{ }^{*} \text { CHI: but everybody called me } \\
\text { horrid }\end{array}$ \\
\hline 3 & 06 & PVR & $\begin{array}{l}\text { *CHI: er when you put it down } \\
{ }^{*} \mathrm{CHI} \text { : look it sucks all the } \\
\text { water up } \\
{ }^{*} \text { CHI: now give it to me } \\
\quad * \text { CHI: and that one blew away }\end{array}$ \\
\hline
\end{tabular}




\begin{tabular}{|c|c|c|c|}
\hline \multirow{3}{*}{3} & \multirow{3}{*}{07} & & ${ }^{*} \mathrm{CHI}$ : you made me dizzy \\
\hline & & \multirow[t]{2}{*}{$\begin{array}{l}\text { PVR } \\
\text { PVR } \\
\text { BR }\end{array}$} & $\begin{array}{l}\text { *CHI: can I switch } \\
\text { them off? } \\
{ }^{*} \text { CHI: let's put the light on } \\
{ }^{*} \text { CHI: turn the light out . } \\
{ }^{*} \text { CHI: just sit down there , } \\
\text { Mum. } \\
{ }^{*} \text { CHI: put him out . }\end{array}$ \\
\hline & & & *CHI: now let's get ready . \\
\hline \multirow[t]{3}{*}{3} & \multirow[t]{3}{*}{08} & PVR & $\begin{array}{l}* \text { CHI: you messed up my pile } \\
\text { again . } \\
{ }^{*} \text { CHI: I put it on my [: actually } \\
\text { says me] head then it falls down }\end{array}$ \\
\hline & & $\mathbf{R R}$ & $\begin{array}{l}{ }^{*} \mathrm{CHI} \text { : crushes it <all up in }>[>] \\
\text { pieces . }\end{array}$ \\
\hline & & BR & $\begin{array}{c}{ }^{*} \text { CHI: we } \\
\text { strawberries . }\end{array}$ \\
\hline \multirow[t]{2}{*}{3} & \multirow[t]{2}{*}{09} & BR & $\begin{array}{l}{ }^{*} \text { CHI: and you can call the fire } \\
\text { brigade [?] } \\
{ }^{*} \text { CHI: I will get you some hot } \\
\text { water . } \\
{ }^{*} \text { CHI: oh give me that little bit } \\
\text { please. }\end{array}$ \\
\hline & & & $\begin{array}{l}{ }^{*} \mathrm{CHI}: \mathrm{I} \text { Oam }\left[{ }^{*}\right] \text { getting closer, } \\
\text { mister bee . }\end{array}$ \\
\hline \multirow[t]{2}{*}{3} & \multirow[t]{2}{*}{10} & BR & $\begin{array}{c}\text { *CHI: or you might get } \\
\text { splashed on it . }\end{array}$ \\
\hline & & PVR & $\begin{array}{l}\text { *CHI: look , I dip this all in . } \\
\text { *CHI: I get up . } \\
\text { *CHI: I'm just rolling my } \\
\text { sleeves up . }\end{array}$ \\
\hline
\end{tabular}




\begin{tabular}{|c|c|c|c|}
\hline & & & $\begin{array}{l}\text { *CHI: you can finish mine off } \\
* \text { CHI: scrape all the chocolate } \\
\text { off }\end{array}$ \\
\hline 3 & 11 & BR & $\begin{array}{l}{ }^{*} \mathrm{CHI} \text { : in my till then he gives } \\
\text { me new money. } \\
{ }^{*} \mathrm{CHI} \text { : I will do this to make } \\
\text { you silly. }\end{array}$ \\
\hline 4 & 00 & $\begin{array}{l}\text { BR } \\
\text { PVR }\end{array}$ & $\begin{array}{l}* \text { CHI: }<\text { and I }>[/ /] \text { I'm gonna [: } \\
\text { going to] make a bigger house . } \\
\quad * \text { CHI: will her hearing aid } \\
\text { come out when she swims? } \\
{ }^{*} \text { CHI: because I keep falling } \\
\text { over and hurting [= actually says } \\
\text { hurt] my legs. }\end{array}$ \\
\hline 4 & 01 & PVR & 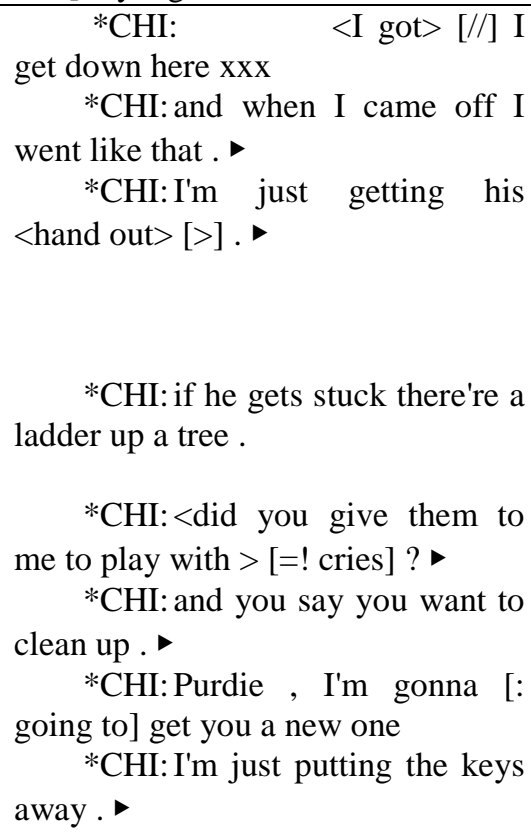 \\
\hline 4 & 02 & PVR & $\begin{array}{l}{ }^{*} \text { CHI: and <then we'll }[?]>[/ /] \\
\text { then we can put them back where } \\
\text { they were. } \\
{ }^{*} \text { CHI: they have_to jump down } \\
+/ \text { [+ IN] } \\
{ }^{*} \text { CHI: } \\
\text { my police station I'm coming out of }\end{array}$ \\
\hline
\end{tabular}




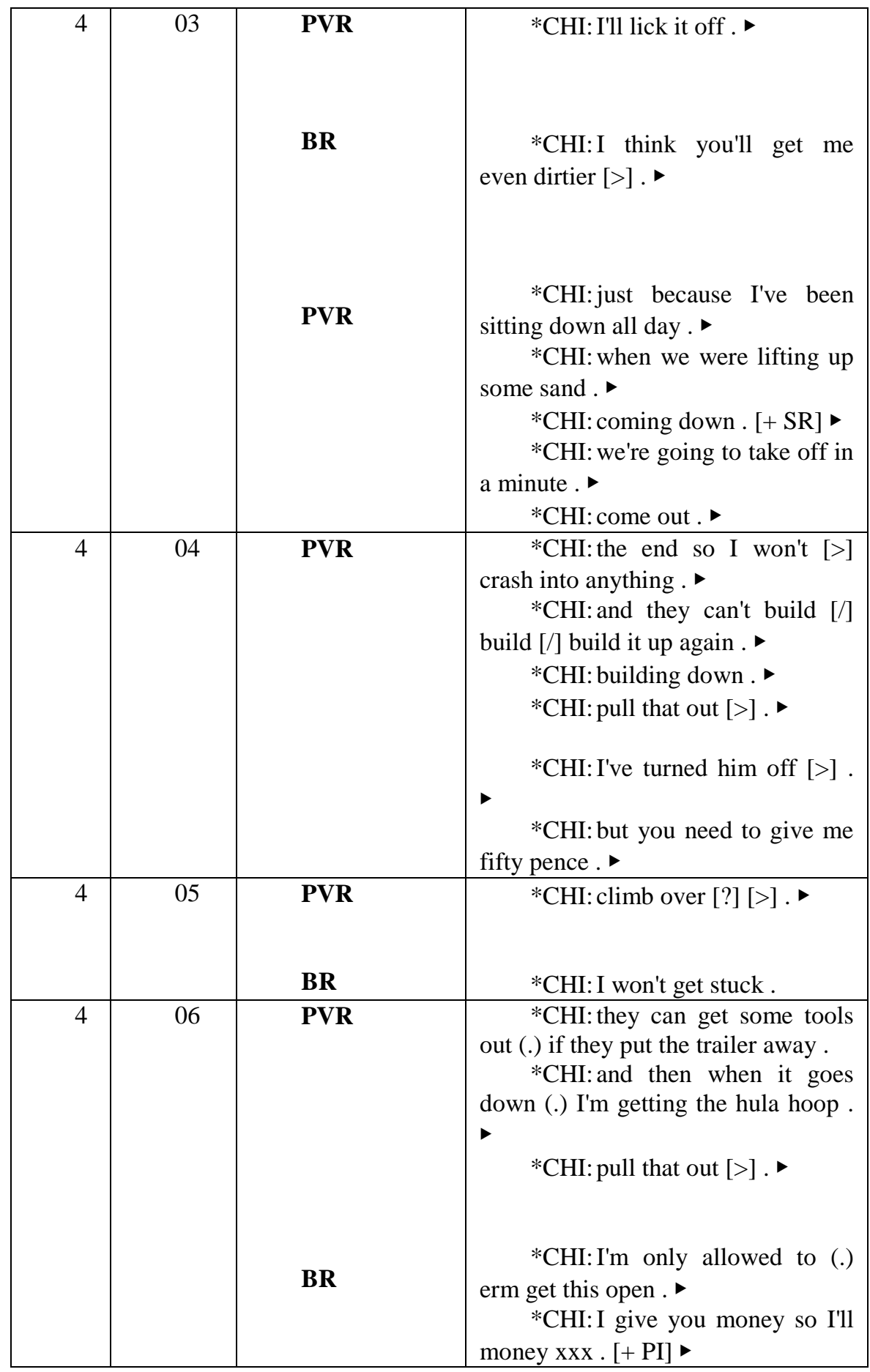




\begin{tabular}{|c|c|c|c|}
\hline & & & *CHI: give her some. \\
\hline 4 & 07 & PVR & $\begin{array}{l}{ }^{*} \text { CHI: get up xxx } .[+\mathrm{PI}] \\
{ }^{*} \text { CHI: I can get down on me }\left[{ }^{*}\right] \\
\text { own . } \\
\left.{ }^{*} \text { CHI: I'm gonna [: going to }\right] \\
\text { fall down Jeannine. }\end{array}$ \\
\hline 4 & 08 & PVR & $\begin{array}{l}{ }^{*} \text { CHI: lean }[<] \text { down here and } \\
\text { I'll show you . } \\
{ }^{*} \text { CHI: it has come out. } \\
{ }^{*} \text { CHI: yeah but }(.) \text { one [/] one } \\
\text { of the pages might blow away. } \\
{ }^{*} \text { CHI: let um if it's broken } \\
\text { down. } \\
{ }^{*} \text { CHI: I always get dirty when } \\
\text { I'm going this way . } \\
{ }^{*} \text { CHI: (be)cause then they'll get } \\
\text { stuck. } \\
{ }^{*} \text { CHI: I need to move (be)cause } \\
\text { I'm < getting very fat> }\end{array}$ \\
\hline 4 & 09 & PVR & $\begin{array}{l}{ }^{*} \text { CHI: fall down this hole } \\
{ }^{*} \text { CHI: }<\text { put it down }>[<] \\
{ }^{*} \text { CHI: taxis }[/] \text { taxis can go } \\
\text { down there now , can't they ? } \\
\text { *CHI: xxx put away . [+ PI] } \\
\text { *CHI: <I want to get paid }>[/] \mathrm{I} \\
\text { want to get paid }\end{array}$ \\
\hline 4 & 10 & PVR & $\begin{array}{l}{ }^{*} \text { CHI: then it could fall down } \\
{ }^{*} \text { CHI:I'm taking that <sock } \\
{ }^{*} \text { CHI: and there's a berry [?] } \\
\text { coming down . } \\
{ }^{*} \text { CHI: turn all the lights on [>] }\end{array}$ \\
\hline
\end{tabular}




\begin{tabular}{|c|c|c|c|}
\hline & & & $\begin{array}{l}\text { *CHI: on there because I've got } \\
\text { my wet. } \\
{ }^{*} \text { CHI: I'll give you a ticket. } \\
{ }^{*} \text { CHI: this will make you } \\
\text { slower. }\end{array}$ \\
\hline 4 & 11 & PVR & $\begin{array}{l}\text { *CHI: will you sit down in my } \\
\text { house where I won't see you . } \\
{ }^{*} \text { CHI: and then it comes down } \\
\text { here again and } \\
\text { *CHI: the trees would either } \\
\text { blow down in the wind or that's a } \\
\text { lumberjack. } \\
\text { *CHI: it's good when the } \\
\text { sausage machine's turned off. } \\
{ }^{*} \text { CHI: I won't smash into your } \\
\text { house. } \\
\text { *CHI: I didn't call it anything. }\end{array}$ \\
\hline
\end{tabular}


Appendix 3: resultative constructions collected in Lara (Rowland and Fletcher's corpus, CHILDES, MacWhinney, 2000)

\begin{tabular}{|c|c|c|c|c|}
\hline YEAR & MONTH & TYPE OF & \multicolumn{2}{|c|}{ UTTERANCE } \\
\hline 1 & 09 & PVR & $\begin{array}{r}* \mathrm{CHI}: \\
* \mathrm{CHI}: \\
\text { down }\end{array}$ & $\begin{array}{l}<\text { all fall down> } \\
\text { more all fall }\end{array}$ \\
\hline 1 & 10 & PVR & 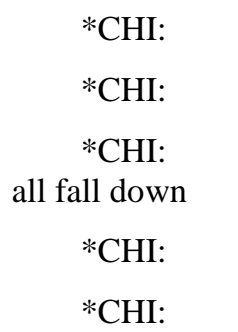 & $\begin{array}{l}\text { fall down } \\
\text { mummy get out } \\
\text { mummy moo } \\
\text { Lara sit down } \\
\text { sit back }\end{array}$ \\
\hline 1 & 11 & PVR & $\begin{array}{l}\text { *CHI: come } \\
\text { *CHI: } \\
\text { *CHI: } \\
\text { *CHI: } \\
\text { *CHI: } \\
\text { *CHI: } \\
\text { *CHI: } \\
\text { *CHI: }\end{array}$ & $\begin{array}{l}\text { out } \\
\text { all fall down } \\
\text { sit down } \\
\text { lie down } \\
\text { come out } \\
\text { Lara get out } \\
\text { put it away } \\
\text { take it (a)way }\end{array}$ \\
\hline 2 & 00 & PVR & $\begin{array}{l}\quad * \mathrm{CHI}: \\
\text { cuddle } \\
\quad * \mathrm{CHI}: \\
\left.\text { put> }{ }^{*}\right] \text { it back }\end{array}$ & $\begin{array}{l}\text { give mummy } \\
\text { mummy <to }\end{array}$ \\
\hline 2 & 02 & PVR & $\begin{array}{r}* \mathrm{CHI}: \\
* \mathrm{CHI}: \\
* \mathrm{CHI}: \\
\text { waking up } \\
* \mathrm{CHI}: \\
* \mathrm{CHI}:\end{array}$ & $\begin{array}{l}\text { that go down } \\
\text { lie down } \\
\text { now you } \\
\text { I sit down } \\
\text { take Heidi out }\end{array}$ \\
\hline
\end{tabular}




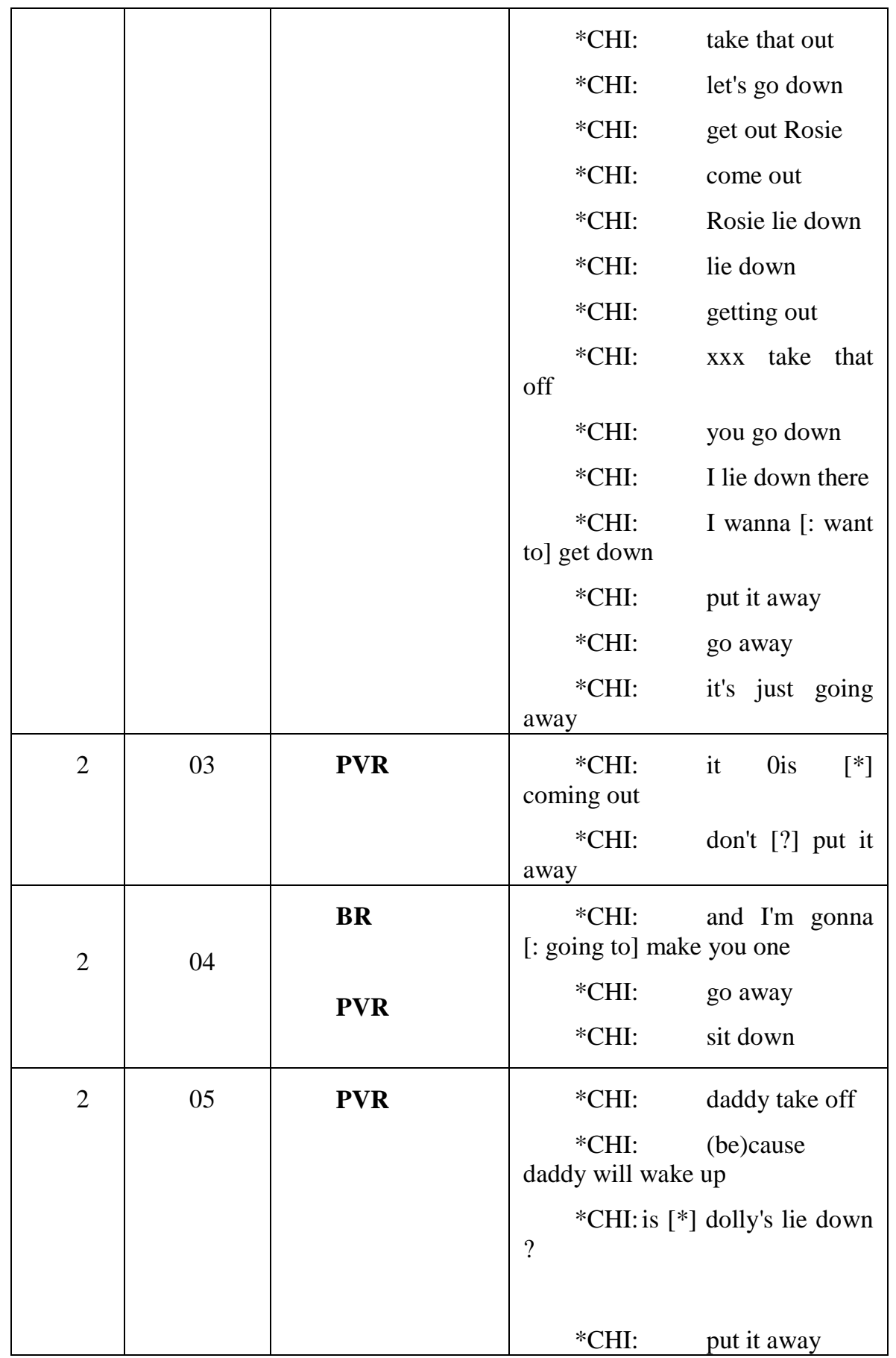




\begin{tabular}{|c|c|c|c|}
\hline 2 & 06 & PVR & 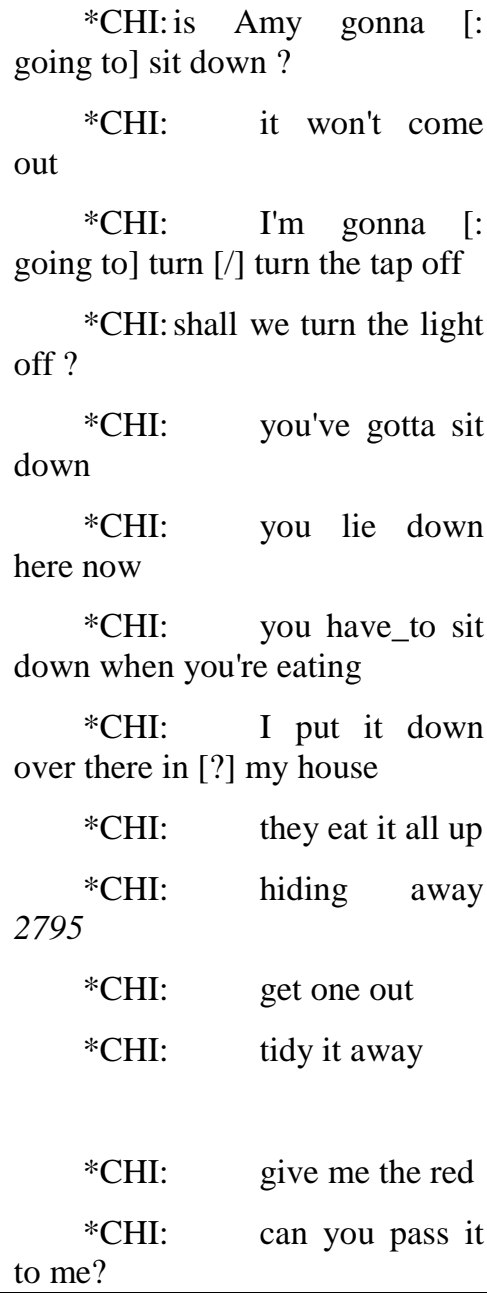 \\
\hline 2 & 07 & PVR & $\begin{array}{l}\text { *CHI: put your dinner } \\
\text { down } \\
\text { *CHI: shall we put } \\
\text { them all back in again? } \\
\text { *CHI: can I take this } \\
\text { off? } \\
\text { *CHI: I will put butter on. } \\
\text { *CHI: we can't get out. } \\
{ }^{*} \mathrm{CHI} \text { : can I lift Amy up } \\
\text { when you do it? }\end{array}$ \\
\hline
\end{tabular}




\begin{tabular}{|c|c|c|c|}
\hline & & BR & $\begin{array}{l}{ }^{*} \text { CHI: take your nappy off , } \\
\text { Rosie } \\
\text { *CHI: sitting her down . } \\
\text { *CHI: don't turn that light } \\
\text { off . } \\
\text { *CHI: called Daddy } \\
\text { *CHI: what about (.) } \\
\text { their dinner getting cold? }\end{array}$ \\
\hline 2 & 08 & PVR & 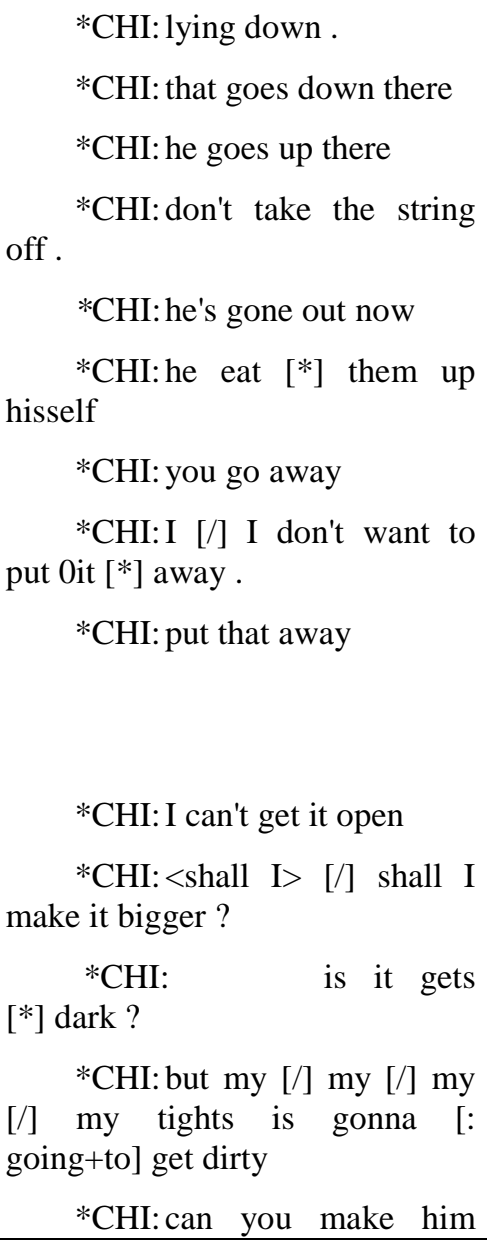 \\
\hline
\end{tabular}




\begin{tabular}{|c|c|c|c|}
\hline & & & $\begin{array}{l}\text { stand up ? } \\
\quad * \text { CHI: they're not getting } \\
\text { burnt . }\end{array}$ \\
\hline 2 & 09 & PVR & $\begin{array}{l}{ }^{*} \text { CHI: shall I move my xxx } \\
\text { out ? } \\
\text { ? }{ }^{*} \text { CHI: can you take them off } \\
{ }^{*} \text { CHI: he's lying down } \\
{ }^{*} \text { CHI: lie down and go to } \\
\text { sleep } \\
* \text { CHI: sit down } \\
* \text { CHI: can you get 0the }[*] \\
\text { camera out for me and Amy? } \\
* \text { CHI: get out. } \\
\text { put it up again } \\
* \text { CHI: it goes down } \\
* \text { CHI: let me take it off } \\
* \text { CHI: lie down. }\end{array}$ \\
\hline & & BR & $\begin{array}{l}* \text { CHI: when Amy get } \\
\text { bigger } \\
\quad * \text { CHI: getting cool } \\
* \text { CHI: make it bigger } \\
* \text { CHI: you say go away giant }\end{array}$ \\
\hline 2 & 10 & BR & $\begin{array}{l}\text { *CHI: I'm making this } \\
\text { bigger } \\
\text { *CHI: you're called smelly } \\
* \text { CHI: he doesn't give him } \\
\text { ninety nine p@1 }\end{array}$ \\
\hline & & PVR & $\begin{array}{l}\text { *CHI: you put it away. } \\
\text { *CHI: she's taking that away }\end{array}$ \\
\hline
\end{tabular}




\begin{tabular}{|c|c|c|c|}
\hline & & & $\begin{array}{l}\text { *CHI: fall down } \\
\text { *CHI: you got it out } \\
\text { *CHI: I need to write } \\
\text { something down } \\
\text { *CHI: go away little } \\
\text { mummy } \\
\quad \text { *CHI: I get out } \\
\text { *CHI: come down here }\end{array}$ \\
\hline 2 & 11 & PVR & $\begin{array}{l}{ }^{*} \text { CHI: got nice tidy and } \\
\text { clean } \\
{ }^{*} \text { CHI: can't get my train } \\
\text { mended } \\
{ }^{*} \text { CHI: and it's getting dirtier } \\
{ }^{*} \text { CHI: I'm trying to make it } \\
\text { bigger } \\
{ }^{*} \text { CHI: I'm called mummy } \\
{ }^{*} \text { CHI: \&er is Lara getting } \\
\text { bigger ? } \\
{ }^{*} \text { CHI: am I getting smaller } \\
\text { now ? } \\
{ }^{*} \text { CHI: }<\text { is that }>\text { [*] called } \\
\text { hail stones ? } \\
\quad{ }^{*} \text { CHI: give it to me then } \\
{ }^{*} \text { CHI: lift your head up } \\
{ }^{*} \text { CHI: wants to be lying } \\
\text { down } \\
{ }^{*} \text { CHI: she's gone to write } \\
\text { something down } \\
{ }^{*} \text { CHI: want get some of my } \\
\text { toys out }\end{array}$ \\
\hline
\end{tabular}




\begin{tabular}{|c|c|c|c|}
\hline & & & 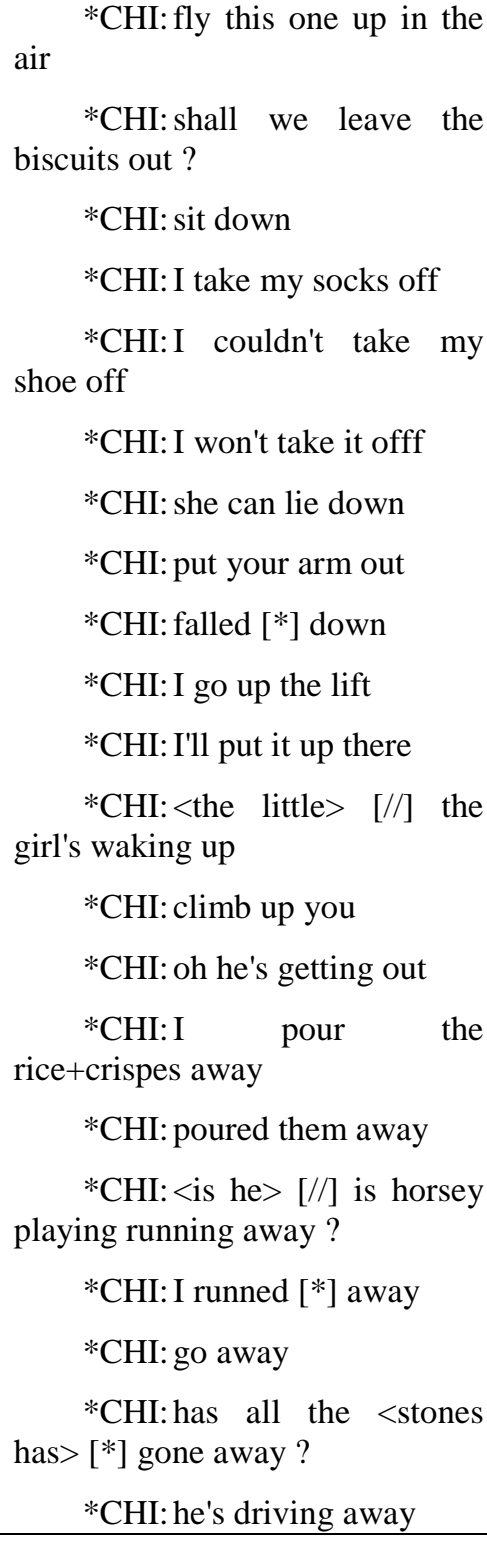 \\
\hline 3 & 00 & PVR & $\begin{array}{l}\text { *CHI: baby go down the } \\
\text { slide } \\
\quad * \text { CHI: can you take the } \\
\text { ticket off? } \\
\quad * \text { CHI: get out }\end{array}$ \\
\hline
\end{tabular}




\begin{tabular}{|c|c|c|c|}
\hline & & BR & $\begin{array}{l}\text { *CHI: fall down } \\
\text { *CHI: lie down if you want } \\
\text { to on the sofa . } \\
\text { *CHI: do you want to sit } \\
\text { down with your drink on the } \\
\text { floor? } \\
\quad * \text { CHI: she wants to take her } \\
\text { jumper off } \\
\quad * \text { CHI: fall down } \\
\quad * \text { CHI: take my socks off too } \\
\quad * \text { CHI: sit down } \\
\quad * \text { CHI: I don't want to put it } \\
\text { away } \\
\quad * \text { CHI: take it away from her } \\
\quad * \text { CHI: you can take him } \\
\text { away } \\
\quad * \text { CHI: it's blown away in the } \\
\text { wind }\end{array}$ \\
\hline 3 & 01 & PVR & 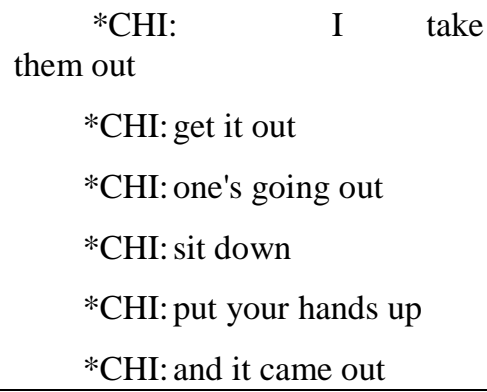 \\
\hline
\end{tabular}




\begin{tabular}{|c|c|c|c|}
\hline & & BR & 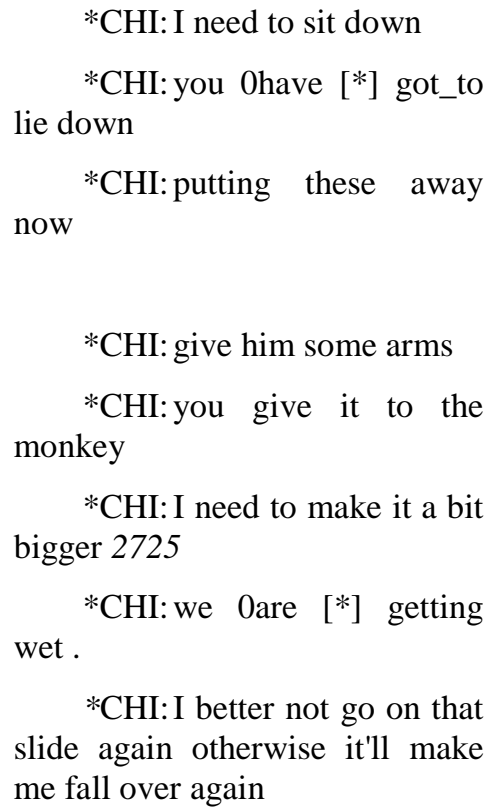 \\
\hline 3 & 02 & PVR & 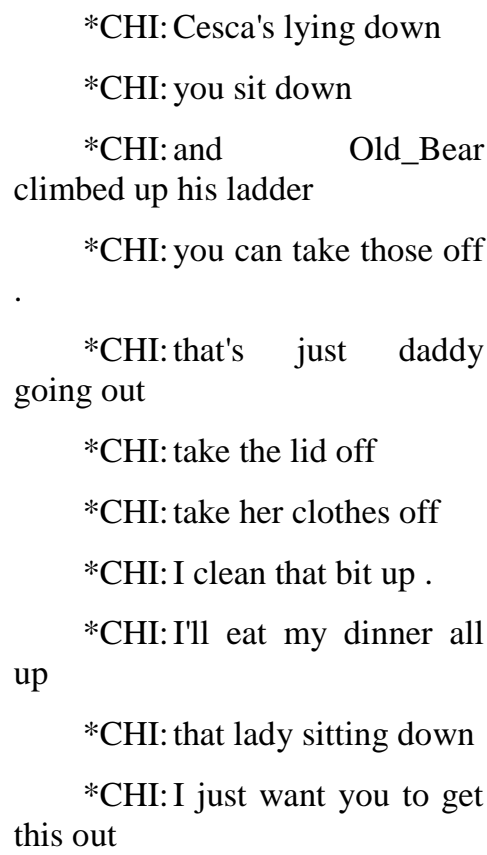 \\
\hline
\end{tabular}




\begin{tabular}{|c|c|c|c|}
\hline & & $\mathbf{B R}$ & $\begin{array}{l}* \text { CHI: I can't make it work } \\
*^{*} \mathrm{CHI} \text { : give her a hug } \\
{ }^{*} \mathrm{CHI} \text { : give her to me }\end{array}$ \\
\hline 3 & 03 & PVR & $\begin{array}{l}{ }^{*} \text { CHI: I'm called Howie } \\
{ }^{*} \text { CHI: I was trying to get } \\
\text { some and you were trying to get } \\
\text { some and you got some and I } \\
\text { make it down } \\
{ }^{*} \text { CHI: I call it bum } \\
{ }^{*} \text { CHI: that's called Harry } \\
\text { and that's called Martin } \\
{ }^{*} \text { CHI: she's not called Amy } \\
{ }^{*} \text { CHI: we can't call me } \\
\text { Frances } \\
{ }^{*} \text { CHI: we could call me } \\
\text { Amy } \\
\text { *CHI: I'm getting right in } \\
\text { pirate ship } \\
{ }^{*} \text { CHI: Amy's getting wet } \\
{ }^{*} \text { CHI: will you get wet? } \\
{ }^{*} \text { CHI: I want you to help me } \\
\text { make it big } \\
{ }^{*} \text { CHI: because if people get } \\
\text { sick I will open it } \\
{ }^{*} \text { CHI: don't like you lying } \\
\text { down } \\
{ }^{*} \text { CHI: it's going down there } \\
{ }^{*} \text { CHI: we 0are [*] sitting } \\
\text { down in back } \\
{ }^{*} \text { CHI: why're you going out } \\
\text { *CHI: let's put these down } \\
\text { now }\end{array}$ \\
\hline
\end{tabular}




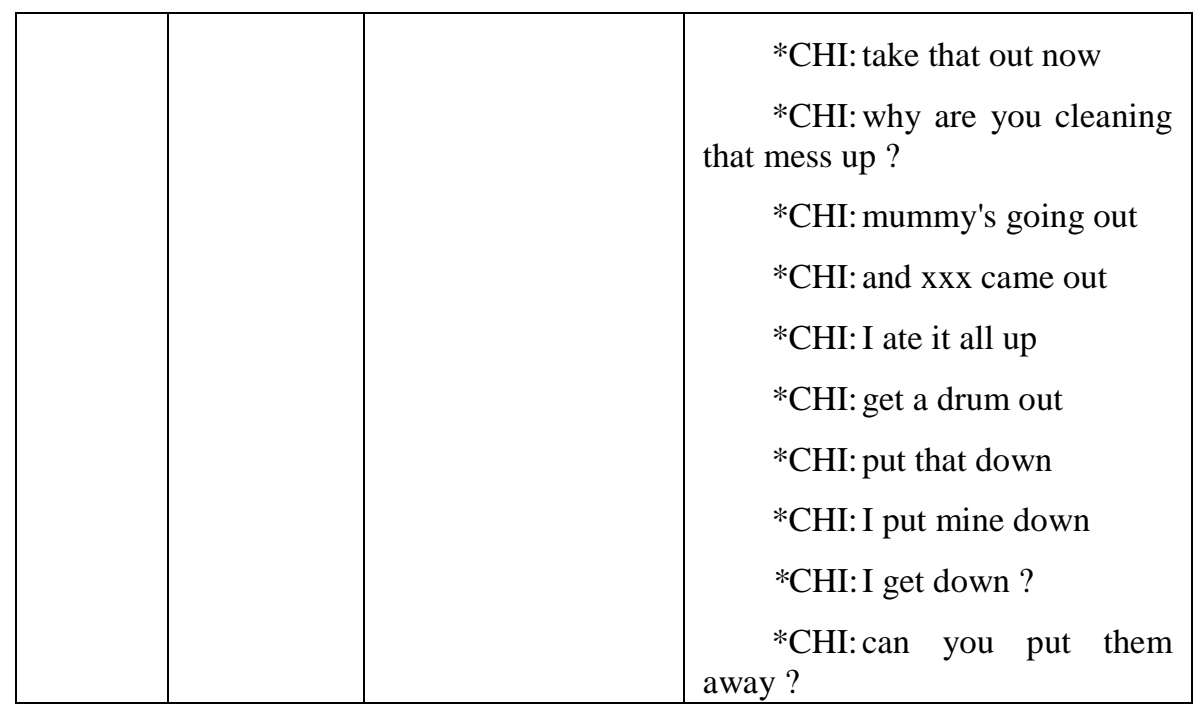

Received: 07 August 2015

Accepted: 23 November 2015 